\title{
Post-Soviet Transformations of Health Systems in the South Caucasus
}

\author{
Sophie Hohmann \\ CERCEC, Paris, France \\ so_hohmann@hotmail.com \\ Cécile Lefèvre \\ Université Paris Descartes, Sorbonne Cité and INED, Paris, France \\ lefevre@ined.fr
}

\begin{abstract}
This article analyzes post-Soviet changes to the health systems in the three South Caucasus countries of Armenia, Azerbaijan, and Georgia. After a severe economic and social crisis and deindustrialization in the 1990s, divergent trends emerged in the 200os. Azerbaijan saw a spectacular recovery in growth, fuelled by an oil boom, while the impact of the 2009 global crisis restrained Georgia and Armenia's capacity to allocate budgets to health care. Many similarities can be identified between the three countries, particularly in the 1990s, attributed to a common Soviet past and to the same trends in international aid. Differences and country-specific features increasingly manifested themselves in the 200os, and resulting from diverging policy choices.
\end{abstract}

\section{Keywords}

Healthcare - Armenia - Georgia - Azerbaijan - reform - privatization

This article seeks to describe and analyze recent changes to the health systems in the three South Caucasus countries of Armenia, Azerbaijan, and Georgia (map 1). Most academic research on the region deals with geopolitical or

* This article was finished in the fall of 2012 and does not discuss events or developments which occurred in 2013 . 
Geopolitical map of the Caucasus Region (2008)

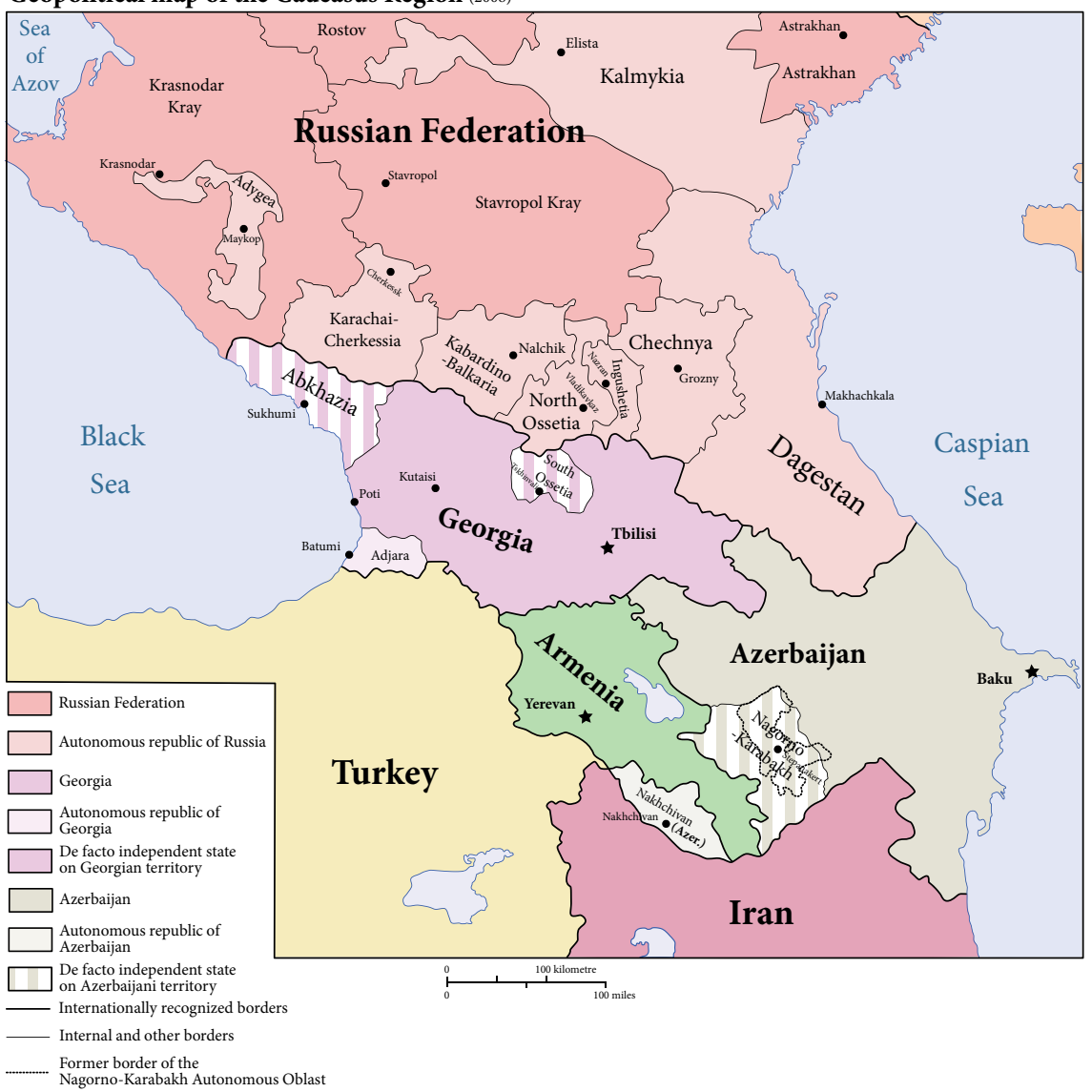

SOURCE : WIKIPEDIA, FREE ENCYCLOPEDIA.

geostrategic issues. Little attention has been paid to the living standards of the population or the transformation of social institutions in the post-Soviet period. There are, of course, numerous reports by international organizations - such as the World Health Organization (WHO), World Bank, Asian Development Bank (ADB), and the United Nations Population Fund (UNFPA) - which deal primarily with the financing of the healthcare system but academic research remains scant. One of the Soviet Union's much vaunted achievements was social policy, particularly the system of free, universal health care. This prompts us first to determine how free and universal the health system was in practice, and whether the "Soviet model" of health care was implemented uniformly across the country or whether there were variations between the republics. Accordingly, this poses the following questions: how have the health systems in the former Soviet republics changed in the past twenty years, in relation to variations on 
the Soviet model and challenges to them since the dismantling of the Soviet Union? Do institutional trajectories differ between countries? And, if so, why?

Since they gained independence in 1991 and, even more visibly since 2000, Armenia, Georgia and Azerbaijan have developed different demographic and social trajectories (see Table 1), and complex relationships with Russia and with Western countries. These relationships influence the continuation or rejection of Soviet health policies and the adoption of new models for health systems and their funding. Economic factors also play a role in the divergence of trajectories. Like the rest of the former Soviet Union, the three South Caucasian countries experienced a severe economic and social crisis and deindustrialization in the 1990s, followed by more divergent trends in the 200os (Figure 1). Azerbaijan saw a spectacular recovery in growth, fuelled by an oil boom, while the impact of the 2009 global crisis restrained Georgia and Armenia's capacity to allocate budgets to health care. Economic policy choices have also determined the extent of liberalization and privatization of health care.

Our analysis draws on close knowledge of Soviet-type health and welfare systems (S. Hohmann, 2006, C. Lefèvre, 1995, 2003) and on recent fieldwork $(2011-2012)^{1}$ in the three countries, where we conducted interviews with health policymakers, particularly ministerial staff, as well as with doctors and other medical personnel. Our work on the divergence of institutional trajectories

TABLE 1 Main population indicators for Armenia, Georgia, and Azerbaijan.

\begin{tabular}{|c|c|c|c|c|c|}
\hline & $\begin{array}{l}\text { Total } \\
\text { population } \\
\text { in } 2010 \\
\text { (million) }\end{array}$ & $\begin{array}{l}\text { Total fertility } \\
\text { rate (average } \\
\text { number of } \\
\text { children } \\
\text { per women), } \\
2005^{-2010} \\
\text { average }\end{array}$ & $\begin{array}{l}\text { Median } \\
\text { age (years) } \\
2010\end{array}$ & $\begin{array}{l}\text { Life expectancy } \\
\text { at birth, } \\
2005^{-2010} \\
\text { average (years) }\end{array}$ & $\begin{array}{l}\text { Unemployment } \\
\text { rate, } 2012 \\
\text { (oIT definition, } \\
\text { in } \% \text { ) }\end{array}$ \\
\hline Armenia & 2.963 & 1.74 & 31.6 & 74.0 & $17 \cdot 3$ \\
\hline Azerbaijan & 9.095 & 2.00 & 28.6 & 70.8 & 5.2 \\
\hline Georgia & $4 \cdot 3^{89}$ & 1.80 & 37.0 & 74.2 & 15.0 \\
\hline
\end{tabular}

Source: Population Division of the United Nations Secretariat, World Population Prospects: The 2012 Revision, http://esa.un.org/unpd/wpp/index.htm, International Labour Organization, Labour Statistics Data Base, http://ilo.org. Unemployment Rate Statistics issued from Household Surveys.

1 Hohmann S., 2006, Santé et changement social en Ouzbékistan : recours thérapeutique et politiques sanitaires, $\mathrm{PhD}$ in Social Sciences, EHEss, Paris. Lefèvre C., 1995, "Typologies et 


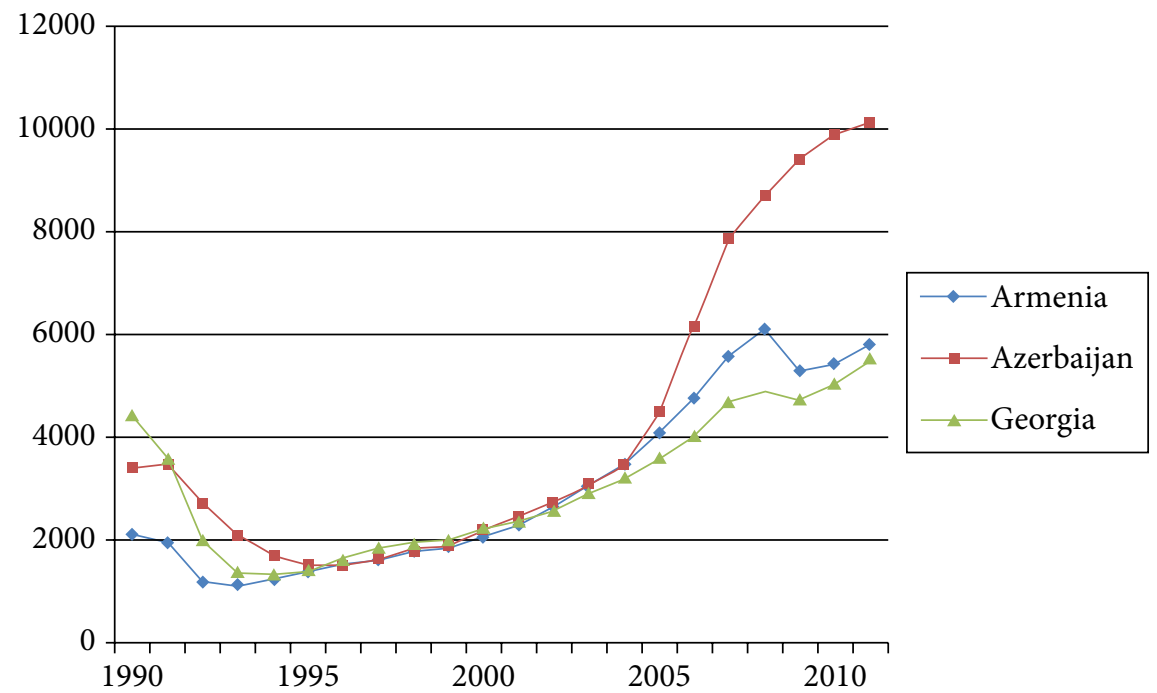

FIGURE 1 Real GDP (PPP\$ per capita) in Armenia, Georgia, Azerbaijan, 1990-2011). SOURCE: WHO, EUROPEAN HEALTH FOR ALL DATABASE: HTTP://WWW.EURO.WHO .INT/HFADB.

builds on studies on the post-Soviet transition from the perspective of path dependency, ${ }^{2}$ applied to health systems.

To enhance our understanding of the trajectories of the health systems in these countries since the breakup of the Soviet Union, it is essential to look first at how the Soviet system operated. Did the system function in the same way across the Soviet Union, or did it exhibit specific features in the South Caucasian republics? The following sections describe the key stages and characteristics of post-Soviet health reform in each of the three countries. What role have international organizations played in the changes to the health system in each country? ${ }^{3}$ What are the chronology and trends of reform? The last section puts forward some hypotheses about the post-Soviet transformation of health systems, in terms of institutional trajectories and change.

grilles de lecture des systèmes de protection sociale: quel enseignement pour la Russie et les pays de l'Est?", Revue Française des Affaires sociales. Lefèvre C., 2003, Système de protection sociales et entreprises en Russie, héritages et transformations, $\mathrm{PhD}$ in Institutional Economics, EHESs, Paris.

2 B. Chavance, "Why National Trajectories of Post-Socialist Transformation Differ?" Journal of Economics and Business V, mo. 1 (2002): 47-65. C. Vincensini, Vingt ans de privatisation en Europe Centrale, Trois trajectoires de propriété (Paris: L'Harmattan, 2010), 318.

3 C. Lefèvre, "Organismes internationaux et protection sociale en Russie," Le Courrier des Pays de l'Est, no. 1040 (2003): 16-25. 


\section{A Common Legacy?}

The Soviet health system delivered consistent health care services in all the republics. It was a unified, wholly state-controlled system, characterized by theoretically ${ }^{4}$ free medical services for all citizens, and based on specialist medicine with a "strategic" focus on prevention. Health care infrastructure was dense, including in rural areas, with an extensive network of health centers (medpunkty) and childbirth centers (fel'dsherskie akusherskie punkty - FAP) across the Soviet Union ${ }^{5}$ and Eastern Europe. The Soviet system is also known as the Semashko system, after Nikolai Semashko, the Soviet Union's first People's Commissar of Public Health (1918-1930), who, sometime before Lord Beveridge, designed a unified, national system of free healthcare, which was introduced in the Soviet Union in the mid-1920s.

However, although coverage was nominally universal and egalitarian, the Soviet health system was in fact compartmentalized into sub-systems, based on socio-economic criteria (with sub-systems for the nomenklatura, employees of large enterprises, miners, etc.) and geographical criteria (the Far North and Siberia, "closed cities", etc.). Informal, inter-personal relationships were also a part of the system, and nominally free services were combined in practice with various relational modalities, bribes, "gratitude payments," and blat ${ }^{6}$ ("connections"). At the local level, these connections were expressed in different ways. For instance in Armenia, these practices were renamed papakh ("under papakh," allusion to the traditional Caucasian hat).

Up until the 196os, the Soviet health system achieved genuine progress in reducing infant and overall mortality, by allocating medical personnel across the national territory, by improving conditions for childbirth, and by tackling infectious diseases. Problems with Soviet health care began to emerge in the 1970s, because the system, focused on the prevention of infectious and parasitic diseases and on increasing the number of hospital beds, failed to take account of the need to combat chronic diseases (diabetes, cardiovascular

4 Article 120 of the First Soviet Constitution enshrined the right of all citizens to full medical assistance free of charge.

5 For more details about the organizational aspects of the health system in the Soviet Union, see F. Cadiot, La santé en URss et en Russie (Presses Universitaires de Strasbourg, 1999), 21-71; M.G. Field, Soviet Socialized Medicine. An Introduction (New York: The Fress Press, 1967), 231; C.M. Davis, "The Organization and Performance of the Contemporary Soviet Health Service," in G.W. Lapidus \& G.E. Swanson, eds, State and Welfare USA/USSR. Contemporary Policy and Practice (Berkeley: University of California, Berkeley, 1988), 95-142.

6 M. Rivkin-Fish, Women's Health in Post-Soviet Russia. The Politics of Intervention (Bloomington and Indianapolis: Indiana University Press, 2005), 253. 
disease, etc.) and make the necessary policy changes. This showed up in demographic indicators in the late 1980s, with stagnating life expectancy and an increase in adult mortality due to cardiovascular disease (Figure 2). Chronically under-funded, burdened by highly centralized management, and with no incentives to use resources efficiently, ${ }^{7}$ the Soviet health system came in for particular criticism and debate during the perestroika period. ${ }^{8}$ In the 1990s, the severe economic crisis that followed the breakup of the Soviet Union left all the former Soviet republics in extremely difficult financial situations. There were drastic cuts to all social spending, including health care.

Soviet practices of informal payment became routine, which resulted in a system that was de facto fee-for-service, as households paid directly for medical care (out-of-pocket costs). ${ }^{9}$ During the phase of economic liberalization

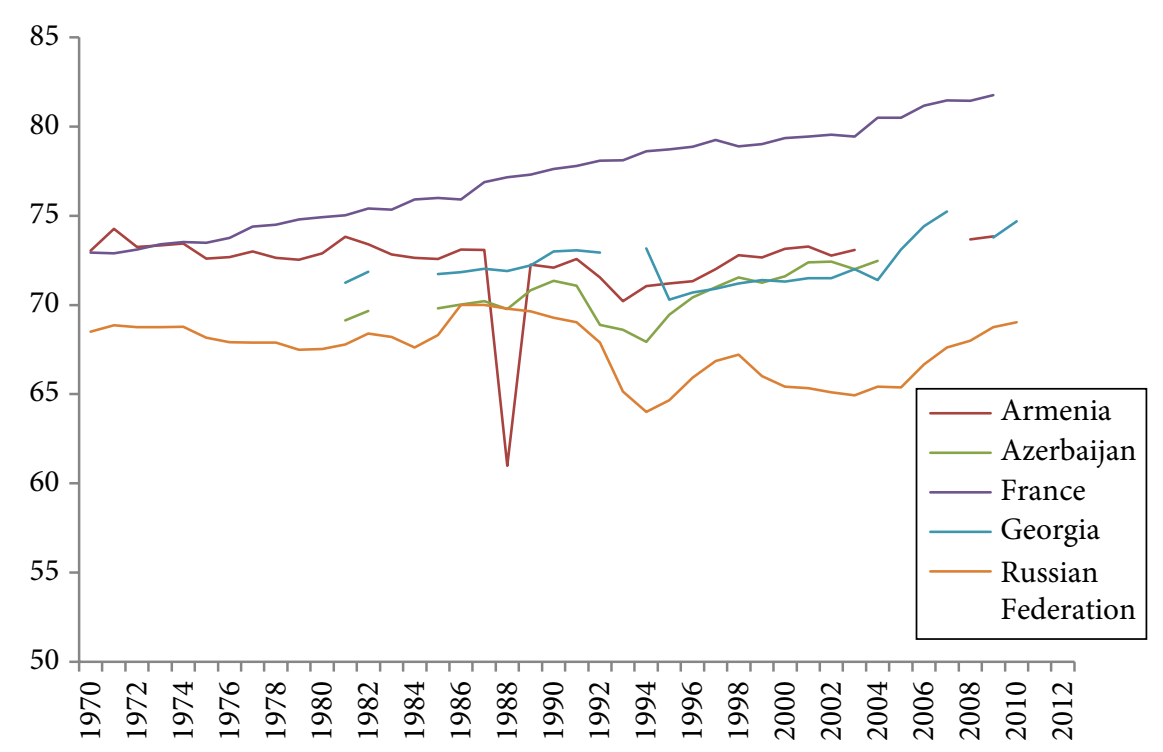

FIGURE 2 Life expectancy at birth (average males/females). SOURCE: WHO, EUROPEAN HEALTH FOR ALL DATABASE: HTTP://WWW.EURO .WHO.INT/HFADB.

Note: The outlier for Armenia is attributable to the sudden, severe impact of the Spitak earthquake in 1988.

7 S. Shiskin, "La réforme du système de financement du système de santé en Russie," Revue d'Etudes Comparatives Est-Ouest 29, no. 3 (1998): 187-206.

8 D. Rowland and A. Teljukov, "Soviet Health Care from Two Perspectives," Health Affairs 10, no 3 (1991): 71-86.

9 S. Shishkin, ed., T. Bogatova, E. Potapchik, et al., "Free Medical Care: Reality and Prospects," IISP Working Paper Series, WP1/2002/07, 216. S. Shishkin, G. Besstremyannaya, M. Krasilnokova 
and both official and "wild" privatization, this encouraged corruption. In the 1990s, the cost and modalities of access to health care by the population were particularly opaque and erratic. Officially, health care was still free, but in practice infrastructure was not maintained, the salaries of medical personnel were almost entirely eroded by inflation and the surge in the cost of living, and payments by patients were completely unregulated (but which made up for some of the shortfall in doctors' low salaries). Simultaneously, the main international organizations (World Bank, UNFPA, USAID) recommended feefor-service payments to overcome the inefficiency of the system. The same recommendations were issued to all three South Caucasian countries, but they were implemented and combined with policies defined nationally to different extents. Different trends in the three countries became visible from the late 1990s onwards.

\section{Armenia: Managing the Soviet Legacy}

\section{9os: Weathering the Storm}

In the 1990s, the Armenian health system did not differ substantively from the Soviet model. Nevertheless, it did have some specific features as follows: a wellreputed medical faculty and a high level of doctor training as well as international scientific exchanges and assistance from the diaspora in procuring medical equipment. For instance in terms of the number of physicians and their training/qualification, the impact of diaspora assistance was significant and rather unique in the South Caucasus (even in the early days of the Armenian Independent Republic (1918-1920); besides it is important to mention the consequences of various repatriations waves bringing more Western knowledge to local practices. However, in the 1970-1980s, the qualification of physicians declined. Further, the health care system became less efficient, failing to reform itself as elsewhere in the USSR, whilst the repercussions of the Spitak earthquake were huge.

Indeed, the Spitak earthquake in 1988 revealed the shortcomings of the public health system, which included outdated equipment and a lack of disposable syringes and dialysis machines. Following the quake, Armenia received substantial international humanitarian aid, which continued into the first years of independence. Subsequently, aid fell sharply, to just 1 percent of health

et al., Health Care in Russia: Payments in Cash (Moscow: State University - Higher School of Economics, 2004), 248. 
spending between 1997 and 2003 (compared to 15 percent between 1990 and 1995). In spite of this, the Armenian diaspora has been very active in terms of assistance since the earthquake and - according to our interviews and observations in the cities and regions of Yerevan and Goris in 2011 and 2012 - would appear to have made a strong contribution in terms of medical equipment, knowledge transfer, and doctor training, although it is difficult to make an overall assessment.

Six months after the earthquake, during the summer of 1989, the Soviet Socialist Republic of Azerbaijan, in the context of the Nagorno-Karabagh conflict, imposed a railway and air blockade against Armenia, suffocating its economy. Despite the steep economic decline, and the harsh political situation, Armenia opted to maintain the principle of a public health system and to preserve vaccination programs and primary health care as a priority, but the available budgets were very low.

\section{2ooos: Structural Change to the Health System}

Several rounds of reform took place after independence, notably in 1993, 1996, and 1997. They embodied the government strategy of focusing on "primary health care development", decentralized and transferred responsibility for (low) state budgets to the regions, and permitted licensed doctors to practice privately from as early as 1993. The reforms formalized fee-for-service payments, but also defined a Basic Benefit Package (ввP) of free health care for welfare recipients, young children, and other population groups (including orphans, children from large families, disabled people, veterans, and Chernobyl "liquidators"), with the potential to be extended gradually to a larger section of the population. The doctors we interviewed stressed the importance of basic free health care as a Soviet legacy, while referring explicitly to the French model of social security.

Reforms in 2004 and 2008 emphasized maternal and child health and the extension of free medical checkups and basic benefits for children up to the age of seven. Particularly indicative is childbirth, which is now officially free of charge. According to the most recent Demographic and Health Survey (DHS), conducted in 2010, 80 percent of women who have given birth since 2008 reported that the service was free. However, "surcharges" are often imposed, and a tradition of "thanking" the obstetrician remains strong among the population.

A key reform of the 1990s, aimed at changing mentalities, was to introduce the function of the family doctor or general practitioner (GP). Armenia was the first former Soviet country to offer training in family medicine. The role and training of family doctors is one of the World Bank's basic recommendations. 
Family medicine was therefore one of the keystones of the Primary Health Care Reform Project in Armenia funded by the World Bank between 1998 and 2003. By 2009, there were approximately 59 family doctors per 100,000 inhabitants in Armenia, compared with 165 in France, for example. In practice, the role of the family doctor is often misunderstood by a population that is used to going to hospital and places legitimacy in specialists. As one of the doctors we met summed it up, "The family doctor reform is stuck."

State policy has focused on the architecture of the system (decentralization, family doctors, primary health care), and external financing (from the diaspora and international organizations) and targeted the renovation of buildings and purchases of equipment, probably for reasons of visibility. The costs of health care are thus incurred to a large extent by households, with out-of-pocket costs accounting for more than 50 percent of total health care costs (compared with around 10 percent in Germany and France), almost go percent of which are informal payments refer to (figure 5). In the city of Goris in southern Armenia, for example, an operation costs around $\$ 1,000$ in 2012, all of which is incurred by the patient. Consequently, self-medication is widespread, with its potential consequences, as is renouncing treatment. Apart from some conditions (chronic diseases like diabetes, and some cancers) for which the state subsidizes medicines, the cost of medicines is an issue for the population. ${ }^{10}$ Almost all medicines are imported and therefore expensive, and there are the additional risks related to drug quality and counterfeiting.

\section{Towards Universal, Compulsory Health Insurance?}

Armenia's health system is largely underfunded, with around 6 percent of the state budget at the end of the 2000s. The need to introduce a new system of health insurance thus emerged, and voluntary private health insurance was legalized in 2004. However, few officially registered insurance companies offer health insurance, and only a tiny percentage of the population is covered chiefly the employees of some private companies and the staff of international organizations. Private health cover is taken out by employers for their employees, rarely by individuals for themselves. Given the substantial informal payments the population already makes, and relatively high premiums, private health insurance is an unattractive option. Furthermore, the poorest population groups, who are the most in need of cover to prevent them from failing to seek vital treatment, cannot afford private health insurance.

10 A. Mouradian, La réforme du système de santé et de la pharmacie dans une ancienne république soviétique, l'Arménie, une transition difficile (PhD, Paris Descartes University, 2008). 
The need for a public health insurance system that would cover the whole population has been discussed by local and international experts, but the issue of how such a system would be funded arose immediately: by tax revenues or by contributions? A scheme based on compulsory contributions that would cover all public-sector employees, as well as veterans and military personnel, is currently being developed. To ensure compliance by employees and employers alike, the system of contributions must be properly understood, in order to overcome certain reservations concerning the system, as expressed by Armenians we interviewed in Yerevan in 2012: "Instead of raising wages, they want to make us pay". An effort to educate the public and explain the services offered and the risks covered therefore seems necessary. The family doctor would be the first port of call and the first prescriber of treatment covered by the compulsory health insurance scheme. The scheme also provides for an increase in the number of family doctors.

\section{Rural Areas Without Doctors}

In the Syunik region of southern Armenia, one village best epitomizes the problems currently facing the health system. The village is located about 12 miles from the nearest town, which has a hospital, but it takes more than an hour to travel there when the roads are passable (which they are not in winter). There has not been a doctor resident in the village for four years, a fact which represents an important loss for the villagers, especially as the last doctor was an active figure in the community. In addition to his work at the dispensary, he taught biology at the local school and lobbied to have the village included in the intervention networks of NGOs and humanitarian aid organizations. When he died, the regional administration, responsible for allocating doctors to dispensaries, did not appoint a permanent doctor to replace him. A town doctor now covers several localities and visits the village dispensary twice a month, which is staffed by a nurse and an assistant, who perform vaccinations and first aid. In many rural regions, doctors in primary health care centers in rural areas are no longer systematically replaced when they die or leave. Two reasons for this are usually given: the decrease in the village population, and rationalization by concentrating doctors in urban health centers and hospitals. The lack of a resident doctor exacerbates the unattractiveness of the village, already affected by substantial labor migration to Russia.

The previous doctor had set up a cooperation project to renovate the village health center, mainly with international aid from a Danish NGO. By mid-2012, the village had a brand-new center and equipment. The center also comprises a pathology laboratory and a pharmacy with three display cases of medicines: one containing medicines for purchase; one containing free medicines 
available for a limited number of nationally defined diseases (cancer, diabetes); and one containing free medicines consisting of humanitarian donations prohibited for sale. The villagers themselves contributed to the renovation of the building, since many have skills from working as migrant laborers on construction sites in Russia. In spite of this, few attend the center: in the two days we spent there, we did not see a single patient. The villagers attribute this to the lack of a permanent doctor, considered a legitimate source of medical knowledge; a decline in the number of children in the village (from 300 to 100 school-age children - aged 6 to 16 - in the space of less than a decade); and mainly to a behavior of renouncing treatment because "even if the first consultation here is free, we won't be able to pay after that."

The main problem for the health system in Armenia is related to funding: a high percentage of costs are incurred directly by the population, some of whom are failing to seek treatment as a result. This is occurring even though the supply of health care services in urban areas, doctor training, and equipment are considered to be of high or very high quality. While free basic health care is currently reserved for infants and young children, there are plans to develop a form of social security, funded by contributions, which would provide basic health care for a larger share of the adult population, but the state ability to fund it is limited.

\section{A Segmented Health System in Azerbaijan}

An oil state at the turn of the twentieth century, Azerbaijan underwent a new oil boom a decade ago as new fields were discovered and borders and markets opened, enabling Western oil companies to sign contracts with the national operator, SOCAR, and gain a foothold in the Caspian Sea. The country's oil and gas reserves generate high rents: by the late 200os, hydrocarbons accounted for more than 90 percent of Azerbaijan's exports, 85 percent of government revenue and almost 80 percent of gross national product. ${ }^{11}$ Per capita GNP rose from $\$ 650$ in 2000 to more than $\$ 6,000$ in 2009. In terms of economic growth and sources of government revenue, Azerbaijan is therefore in an altogether different position from the other two countries in the South Caucasus. ${ }^{12}$ Is it the same with health care?

\footnotetext{
11 J. Radvanyi, ed., Les Etats post-soviétiques, Identités en construction,transformations politiques, trajectoires économiques (Paris: Armand Colin, 2011).

12 R. Mathey, "Futur Emirat du Caucase ?" Le Courrier des Pays de l'Est 1, no. 1065 (2008): 92-105.
} 


\section{A Mismatch Between the Health System on Paper and Reality on the Ground}

Officially, Azerbaijan's health system is still based on the Soviet model of free consultations and care. However, fee-for-service payments, which already existed informally, were formalized for some specialist care in 1994 and again in 1998. Azerbaijan has maintained a centralized health system, unlike its two Caucasian neighbors, which have decentralized health care. The first reforms were implemented in 1994, and in 1997 a law on the protection of health introduced the freedom to choose a doctor. There was a new round of reform in the mid-20oos, and in 2008 the president signed the National Concept on Health Financing Reform, aimed at introducing compulsory health insurance and a basic benefit package, a measure supported by the World Bank, as well as by USAID, UNICEF, and the World Health Organization. The new law stresses the need to raise the quality of the primary health care system, described as "underdeveloped". The introduction of family doctors is advocated and presented by the international organizations involved as the pillar of the new system of primary health care.

Officially, the state remains a major source of funding for the health system. However, the data contradict this assertion, since public spending accounts for only 19.3 percent of total health spending in 2008-2010 (Figure 3), compared with around 40 percent in Armenia, 25 percent in Georgia and almost 80 percent in France. The dramatic increase in GDP since the mid-20oos has not been matched by a proportional increase in health spending, which fell as a percentage of GDP as the economy expanded and then rose slightly (Figure 4). A high percentage of health costs is incurred directly by households (Figure 5), a phenomenon common to all three countries, but which is particularly evident in Georgia and Azerbaijan. More than 70 percent of households appeared to have great difficulty affording health care in the late 200os. ${ }^{13}$ Moreover, we know little about access to health care by persons internally displaced by the conflict with Armenia over Nagorno-Karabakh, who number roughly 790,00o, or almost 10 percent of the population.

The Demographic and Health Survey (DHS) conducted in Azerbaijan in 2006 shows a mismatch between the official presentation of free, universal health care, and the data, particularly infant and maternal mortality rates, which suggest a dysfunctional health system. The infant mortality rate is affected by problems of definition and registration of infant deaths. Azerbaijan is one of the last former Soviet countries (with Uzbekistan ${ }^{14}$ ) not to have

\footnotetext{
13 ADB report, Country Gender Assessment. Azerbaijan (Manilla: ADB, 2005).

14 S. Hohmann, La mortalité chez les jeunes enfants en Ouzbékistan. Des particularismes soviétiques aux réalités contemporaines (Sarrebruck : EUE, 2010), 67.
} 


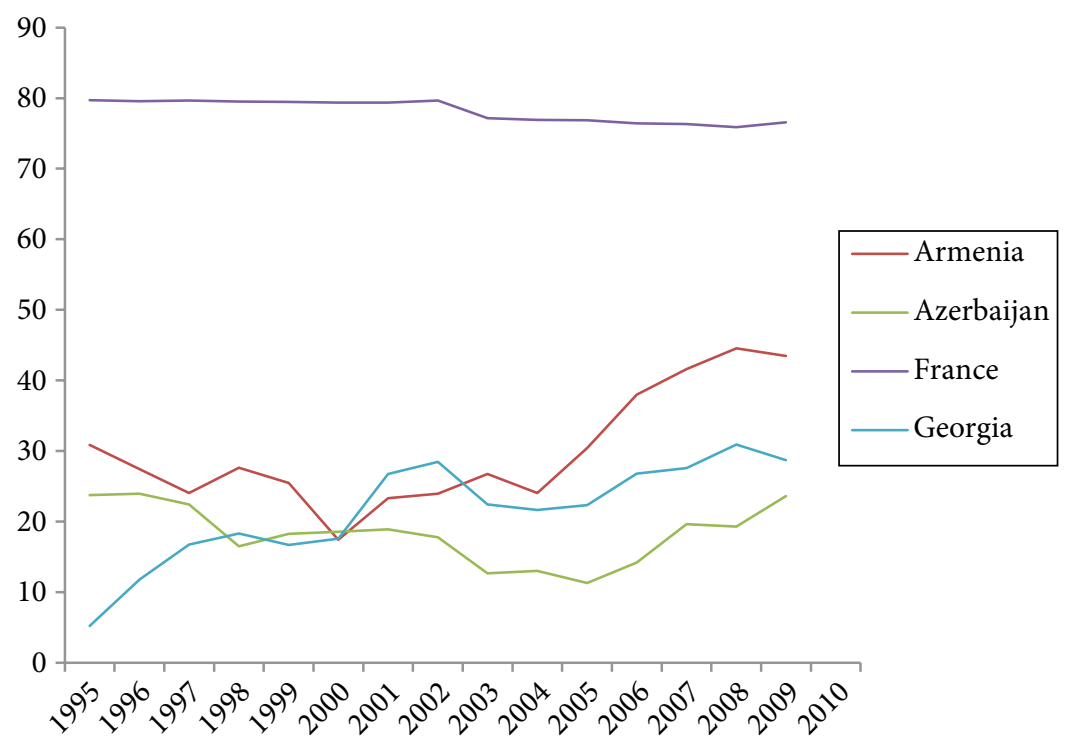

FIGURE 3 Percentage of public spending in total health care spending Macro-economic indicators of health spending in the Caucasus. SOURCE: WHO, HTTP://WWW.EURO.WHO.INT/HFADB.

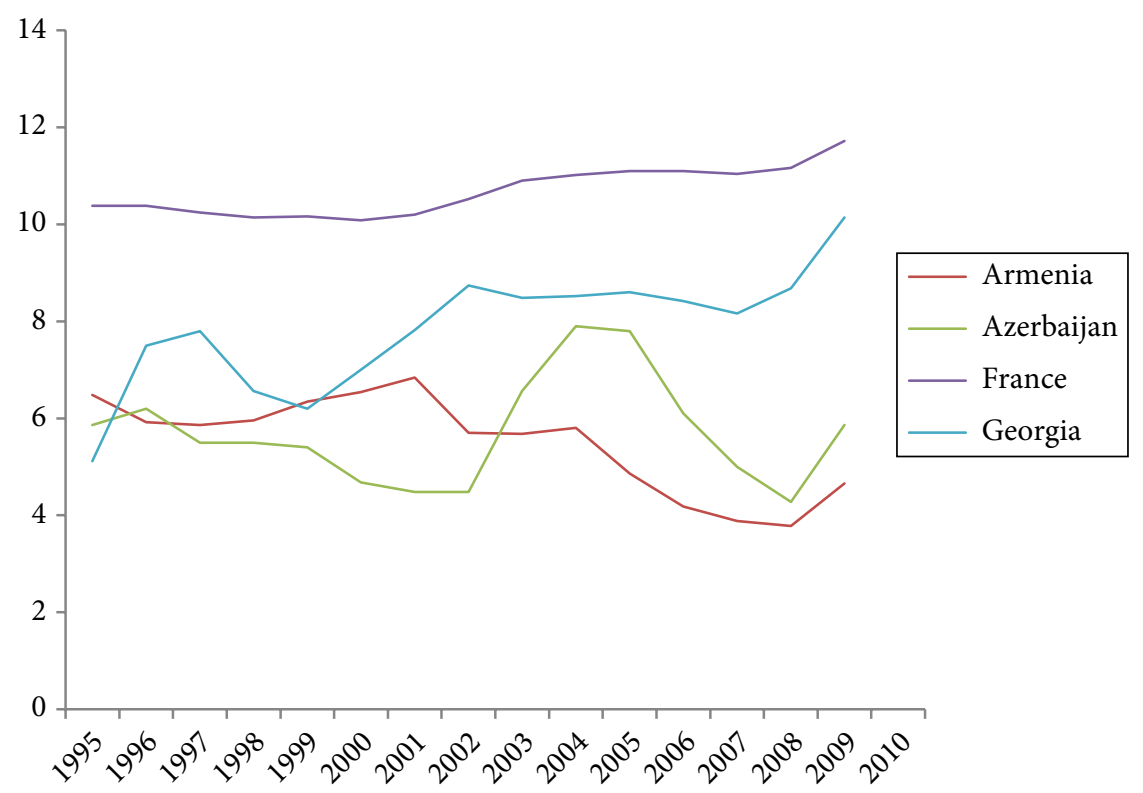

FIGURE 4 Health spending as a percentage of GDP (WHO estimate). SOURCE: WHO, HTTP://WWW.EURO.WHO.INT/HFADB. 
adopted the international definition of infant mortality, which considers the perinatal period to begin at 22 weeks of gestation (when birth weight is normally 500 grams), rather than at 28 weeks of gestation, which revises the definition of a live birth. ${ }^{15}$ The data presented in Table 2 show the differences in level (up to a factor of 9 !) between the official statistics and those from the 2001 Azerbaijan Reproductive Health Survey (ARHS), in particular neonatal mortality rates (within the first 28 days after birth). The differences in post-neonatal mortality rates probably reflect other problems, such as nonregistration of deaths in rural areas by the authorities, or arrangements about the date of death. Differences in infant mortality rates are therefore complex and delicate to decipher. They appear to be partly attributable to incomplete registration and possibly to manipulation of figures by the authorities (transfers of deaths from one age group to another).

\section{A Legal But Still Limited Private Sector}

Unlike in Armenia, and even less so in Georgia, private health care, legalized in 2001, is embryonic in Azerbaijan. Some doctors have managed to set up in private practice after applying for a license from the Ministry of Health and by pooling resources with other doctors to cover the cost of premises. Because doctors working in the public sector are poorly paid, many work simultaneously

TABLE 2 Infant, neonatal, and post-neonatal mortality (per 1,ooo live births): comparison of official statistics and 2001 Azerbaijan Reproductive Health Survey.

\begin{tabular}{|c|c|c|c|c|c|c|}
\hline \multirow[t]{2}{*}{ Year } & \multicolumn{3}{|c|}{ Official Mortality Rates } & \multicolumn{3}{|c|}{ Azerbaijan Reproductive Health Survey } \\
\hline & $\begin{array}{l}\text { Neonatal } \\
\text { mortality } \\
\text { (less than } \\
28 \text { days) }\end{array}$ & $\begin{array}{l}\text { Post-neonatal } \\
\text { mortality } \\
\text { (28 days } \\
\text { to } 1 \text { year) }\end{array}$ & $\begin{array}{l}\text { Infant } \\
\text { mortality } \\
\text { (less than } \\
\text { 1 year) }\end{array}$ & $\begin{array}{l}\text { Neonatal } \\
\text { mortality }\end{array}$ & $\begin{array}{l}\text { Post- } \\
\text { neonatal } \\
\text { mortality }\end{array}$ & $\begin{array}{l}\text { Infant } \\
\text { mortality }\end{array}$ \\
\hline 1993 & 4.6 & 24.0 & 28.6 & 41.2 & $44 \cdot 7$ & $85 \cdot 9$ \\
\hline 1998 & 3.6 & 13.0 & 16.6 & 34.1 & 40.3 & $74 \cdot 4$ \\
\hline $\begin{array}{l}1991- \\
2000\end{array}$ & 4.2 & $17 \cdot 3$ & 21.5 & 38.1 & 40.2 & 80.8 \\
\hline
\end{tabular}

Source: Azerbaijan Reproductive Health Survey (ARHS), CDC-USAID, 2003.

15 WHO, International Classification of Diseases, ICD-10, 1993. http://www.who.int/ classifications/icd/en/ (accessed November 24, 2013). 
part-time in the fledgling private sector to "make ends meet." Private pharmacies were legalized in 1997. As in the other two Caucasian countries, almost all medicines have be to paid for and are often expensive imports, as a female doctor, who opened a private practice in Baku, explained: "I can give you an example. I had the flu, and a basic throat medicine cost 20 manats [around $\$ 25]$. Retired people, whose monthly pension is 100-200 manats, have little left over once they've covered their costs. They really have to avoid getting sick." Access to medicines is a major problem in most post-Soviet countries, but in Azerbaijan and Georgia, the frequently reported practice whereby doctors, pharmacies, and pharmaceutical labs allegedly work together as cartels, exacerbates inequality.

In contrast to Armenia, the quality of medical training seems to have been a problem in Azerbaijan for some years now. The best specialists, as in many other post-Soviet republics, have emigrated permanently. Falsification and corruption (buying degrees and positions) appear to have worsened, leaving little room for those who wish to succeed by non-corrupt means, and serve to undermine medical ethics. Patients are losing confidence in the competence of the country's doctors. According to our interviews, those Azerbaijanis who have the means seek other solutions, travelling to Iran for treatment (Iranian doctors have an excellent reputation), or, for the more affluent, to Turkey.

\section{The Oil Sector: An Autonomous Sub-System?}

The large oil companies have developed their own health systems for their employees, which are independent but subject to authorization from the Ministry of Health. This parallel health system already emerged in the nineteenth century in the midst of the oil boom in Baku (Nobel, Taguiev, Mantachev were notable pioneers in this regard), which, for instance, saw hospitals established for workers in a period of pre-Soviet paternalistic capitalism. Furthermore, during the Soviet period, too, the social protection role played by enterprises can be compared with paternalistic practices After the collapse of the USSR and the subsequent economic crisis, only the biggest Russian companies maintained or renewed such social protection activities, ${ }^{16}$ as well as the oil sector in Azerbaijan. Most companies provide medical and social services only for employees on oil extraction and production platforms,

16 C. Lefèvre, "Enquête sur la politique sociale des entreprises industrielles russes en 1996," Le Courrier des pays de l'Est, no. 427 (1998); C. Lefèvre, "Sotsial'naya rol' predpriatii v Rossii: sluchay paternalizma?" (The social role of entreprises in Russia: a case of paternalism?), Mir Rossii XVII, no. 3 (2008): 149-170. (Lefèvre C., 2003, op.cit). 
which means that their families are not always covered. Salaries (roughly $\$ 4,000$ a month, much higher than the average) seem to be considered high enough for employees to pay for medical care for their families out of their own pockets. In some cases, immediate family members are covered, but only for ordinary consultations and not surgery, the full cost of which is incurred by them.

This is how the health system is partly being privatized, creating multispeed health care. However, there may be some local positive spillover effects. Company social systems can have a diffusion effect that benefits the rest of society through infrastructure. On the opposite shore of the Caspian, near Aktau in Kazakhstan, for example, a road built by an oil company was extended in response to a request from the local authorities so as to improve access to the neighboring villages. Some companies can take a strategic approach to averting social friction by extending roads or renovating schools and dispensaries in the regions where they operate. This is still rare, however, and social problems are frequent, including strikes by workers over unpaid wages and energy supplies that prove inaccessible and unaffordable for populations living near the oil fields.

\section{Georgia: Towards a Free-Market Health Care Model?}

\section{The 199os: A Step Towards Compulsory Health Insurance}

After the collapse of the Soviet Union in 1991, Georgia initially sought to develop a system of compulsory public health insurance, established by a 1995 law. At the same time, the government introduced a list of essential medicines for which co-payment by the patient and the state was formalized. These developments represented a shift away from the Soviet system. Formalized co-payment was also innovative. At the same time, there was some continuity, and the principle of a public health system was reaffirmed.

Policy took a different direction almost immediately, however. The production and distribution of medicines were privatized in 1996, and optional private health insurance was legalized in 1997. Starting in 1998 specialist doctors wishing to practice privately in the primary health care system had to pass an examination so as to be licensed. Family medicine was recognized as a specialization in 1998. However, only a few doctors from the former primary health care system sat the examination, mainly those doctors working in pilot health centers run by international aid programs. Most primary health care facilities continued to operate as they did in the Soviet period, especially in provincial areas. 


\section{A Shift To Liberalization and Privatization in the $2000 \mathrm{~s}$}

After the "Rose Revolution" of 2003 and Mikhail Saakashvili's election as president, major changes in reform philosophy, mode of funding, and organization of health infrastructure were decided upon. ${ }^{17}$ Almost all hospitals were privatized and many primary health care facilities were closed (Figure 6). In 2006, the MIP (Medical Insurance Program for the Poor) program was launched to strengthen the financial protection of the poorest 20 percent of the population. The MIP is financed by taxes and implemented by private insurance companies. Those covered by the program are supposed to have a relatively complete set of health services (the "package") without extra charge. The majority of costs for drugs, however, are not covered. Due to an inefficient system of eligibility, services for about half of the poorest quintile are still not assured and some patients still have to pay for services supposed to be covered by the MIP. Whereas out-of-pocket payments have decreased slightly, they

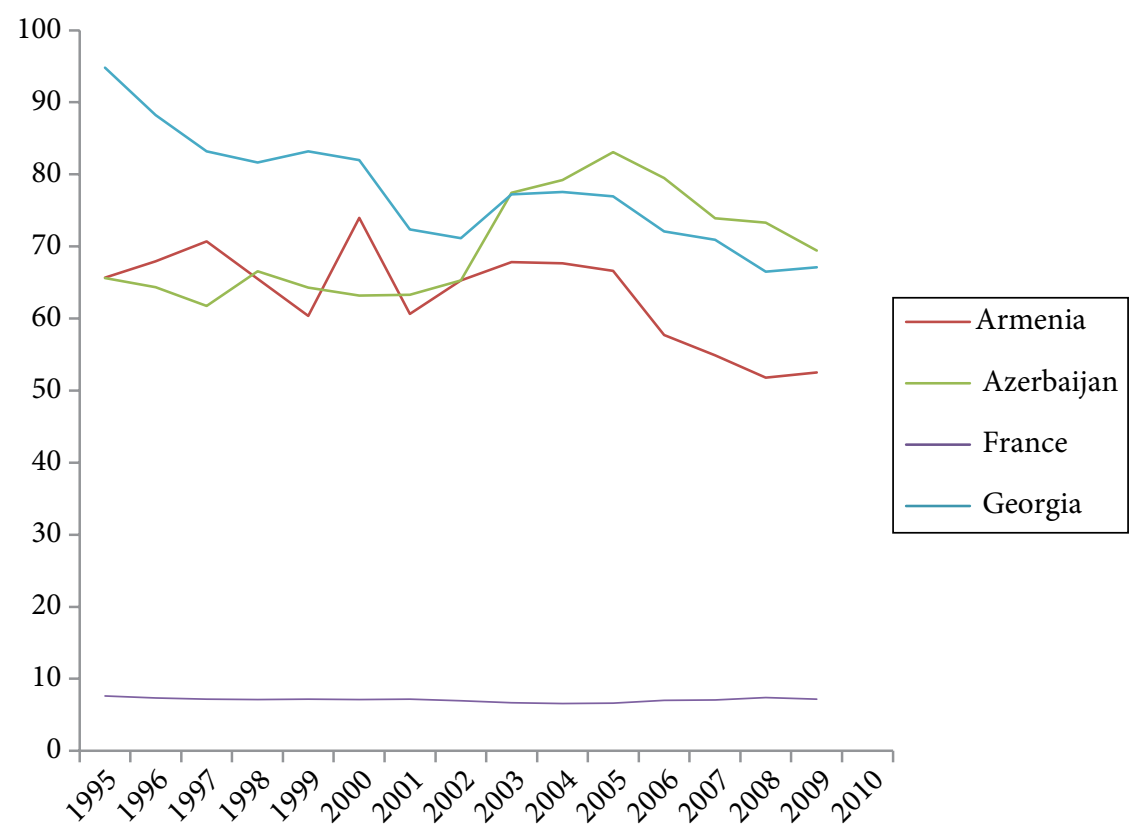

FIGURE 5 Percentage of out-of-pocket spending by households in total health spending Macro-economic indicators of health spending in the Caucasus. SOURCE: WHO, HTTP://WWW.EURO.WHO.INT/HFADB.

17 T. Chanturidze et al., "Georgia. Health system review," Health systems in transition 11, no. 8 (2009); T. Hauschild, E. Berkhout, "Health-Care reform in Georgia, A civil society Perspective: Country case study," Oxfam International Research Report, 2009, 47. 
nonetheless remain exceptionally high, ${ }^{18}$ and around half of these payments are devoted to pharmaceuticals (Figure 5). Notwithstanding, insurance companies have realized huge profits. ${ }^{19}$ For people not covered by the MIP, only a minority can afford to subscribe to private health insurance coverage or earn enough in wages to cover themselves privately. As of 2012, half of the Georgian population remained uncovered and paid for health services out of pocket.

The law on compulsory health insurance was superseded by a dual system: individuals with the means are encouraged to take out health insurance with private insurance companies; while the poorest categories are eligible for free basic health care, via a voucher system, under a new policy of targeted welfare implemented in 2008. The model sometimes explicitly cited is that of the U.S. model, which gives a major role to the private sector, combined with a Medicaid-type system for the poor.

The new free-market policy ${ }^{20}$ has led to the emergence of several private health insurance companies and the construction of new private hospitals since $2008 .^{21}$ The government holds regionalized tenders to build new hospitals, with the twofold aim of reconfiguring the supply of health infrastructure and stimulating the construction sector. The private insurance company that wins the tender receives a several-year monopoly on the provision of health care to the population in the region. By the second half of 2010, 56 new hospitals had been or were being built by insurance companies. The government's strategy of privatizing the hospital sector resulted in the rapid construction of modernly equipped multi-profile hospitals that are owned by private investors. At the regional level, they became monopolist providers, compounded by the existence of potential conflicts of interest between drug companies and private owners of hospitals. ${ }^{22}$ Spending devoted to pharmaceuticals is among the highest in the world, accounting for between 3 and 4 percent of GDP. The market for pharmaceuticals is characterized by high prices, high margins, a powerful cartel that controls their import, as well as wholesale and retail sale. ${ }^{23}$

18 G. Gotsadze, Household catastrophic health expenditure: evidence from Georgia and its policy implications, Curatio International Foundation BMC Health services Research, 2009. Transparency International, The Georgian Hospital Sector (Tbilisi: Transparency International, 2012), 22.

20 E. Baumann, "Géorgie : la difficile équation entre économie néo-libérale et valeurs démocratiques," in M. Dupont-Dobrzynski, and G. Galstyan, eds, Les influences du modèles de gouvernance de l'Union européenne sur les PECo et la CEI (Lyon: Ecole normale supérieure, Institut européen Est-Ouest, 2011).

21 Transparency International, The Georgian Hospital Sector 2012.

22 Ibid.

23 Transparency International, The Georgian Pharmaceutical Market, 2012. 
In practice, doctors in the existing system have been able to "self-privatize," without having to change their workplace or position. Head doctors (glavnye vrachi) of hospitals in effect became company managers. In 2010 an estimated 1,60o rural doctors had become self-employed and were earning roughly 500 laris a month (around \$300). By contrast, the new generation of doctors face major obstacles. Medical graduates rarely have the resources to set up in private practice, and conditions of appointment to private or privatized hospitals are no longer regulated by public bodies. It seems that many young doctors go abroad (Germany and the United States are the most frequently cited destinations) to start or finish specialist training in order to obtain a recognized qualification and find employment there.

From the point of view of the population, the main impact of the reforms has been a sharp increase in the cost of health care and a very high percentage of out-of-pocket payments - around 70 percent of total costs in 2010 (Figure 5). Conversely, the share of public funding in health care funding is very low (less than 20 percent). The bulk of health care funding is incurred by the population directly, because few people have been able or wanted to take out insurance with private insurance companies, and because the basic benefits package for the poor offers a very limited amount of care. Some traditional public health problems, which were thought to have been eliminated, have re-emerged, such as multi-drug-resistant tuberculosis, because of a lack of compulsory screening.

The parliamentary elections in October 2012 were won by President Saakashvili's rival, Bidzina Ivanishvili, who funded infrastructure and made cash and in-kind payments in a number of villages during his election campaign. Beyond these isolated pre-electoral practices, the population's expectations and voting behavior were clearly influenced by welfare issues. Of further interest to study is to what extent the radical privatization of the health system and the accompanying free-market, modernizing discourse will be pursued or reversed in Georgia in the years ahead.

\section{Conclusions: A Common Past, Three Different Trajectories?}

More than twenty years after independence, one now has the hindsight to identify common features and differences in the institutional trajectories of the health systems in Armenia, Azerbaijan, and Georgia. Many similarities can be identified, particularly in the 1990s, attributed to a common Soviet past and to the same trends in international aid. Differences and country-specific features increasingly manifested themselves in the 200os, and seem mainly to have resulted from different policy choices. 


\section{Common trends attributable to the same soviet past}

The situation regarding medicines in the Soviet Union was paradoxical. While some medicines were delivered free of charge at hospitals and health centers, the population in fact purchased many of them, for both common ailments often treated by self-medication - and serious conditions. The production and distribution of medicines were organized within the framework of the division of labor and central planning in the Eastern Bloc. Many of the medicines consumed in the Soviet Union were manufactured in Central Europe, particularly in East Germany. The dismantling of that system caused shortages of medicines and disrupted distribution and supply channels. Today the South Caucasian countries remained heavily dependent on imported drugs. Counterfeit medicines are a common and dangerous problem, ${ }^{24}$ tablets are frequently bought individually rather than in packets, and prescriptions are not common practice.

Another feature inherited from the Soviet health system and common to the three countries is an emphasis on hospitalization, both in terms of the number of beds per capita and the length of hospital stays. Hospitalization was a common practice in Soviet times and reflected state medicine practices based on invasive treatments and heavy protocols. For example, anemic patients would be administered iron intravenously in hospital, rather than by oral tablets at home. Frequent recourse to hospitalization also reflected the extensive growth model, measured by volume indicators, characteristic of Soviet economic planning. The number of hospital beds per 100,000 population was therefore relatively high in the Caucasus, especially in Georgia and Azerbaijan.

In the 1990s, the number of hospital beds contracted sharply in Armenia and Georgia, from 800-1,000 per 100,000 population in 1990 to around 400 in 2000. Bed numbers continued to fall in the 2000s but at a slower pace. The decline in the 1990s was partly the result of an adjustment to the needs and size of the population but was mainly due to the severe economic crisis. In Armenia, the number of hospital beds has been halved since independence. Most of the reduction has occurred in rural areas, whereas cities still have surplus capacity. Whereas Georgia has experienced the same decline, this has been spurred by a different phenomenon - namely the privatization of existing hospitals and the construction of new private hospitals in the late $2000 \mathrm{~s}$ with profitability as a key objective. In the few remaining public hospitals,

24 H. Rousselot, "Le secteur pharmaceutique russe : eldorado pour les laboratoires étrangers?" RSE Revue électronique Regards sur l'Est, October (2005), http://www.regard-est .com/home/breve_contenu.php?id=546 (accessed November 24, 2013). 


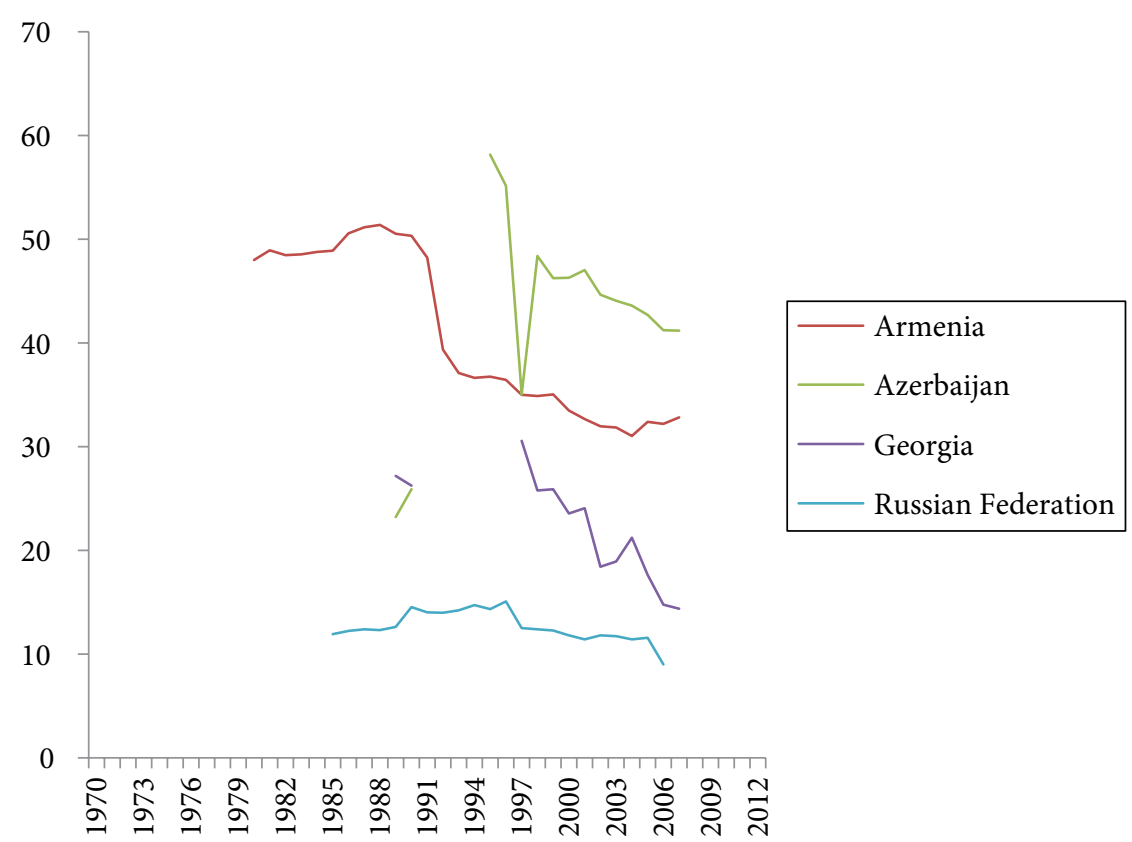

FIGURE 6 Number of primary health care facilities per 100,000 population. SOURCE: WHO, EUROPEAN HEALTH FOR ALL DATABASE: HTTP://WWW.EURO.WHO .INT/HFADB.

beds are hard to get because a portion are used to accommodate internally displaced persons as a result of the conflicts in Abkhazia and South Ossetia. Azerbaijan has maintained a high number of hospital beds and hospital stays are still relatively long, but the occupancy rate has fallen considerably since 1991 to as low as 20 percent in some hospitals.

The end of the Soviet Union also caused a disruption of monitoring and medical observation of treatment for tuberculosis. In Georgia, the rise of multiresistant cases of tuberculosis is a direct consequence of the collapse of the public health system and the process of privatization combined with high level of poverty and migration.

The shift from a centrally planned to market economy has modified the funding of social protection. During the Soviet period, the financing of social protection was provided by social security contributions and the state budget. After 1991, the privatization of the economy resulted in massive layoffs, and many people have found themselves in a difficult situation of unemployment, self-employment, and pluriactivity, which has meant that they have failed to pay contributions. The International Labor Organization recently qualified this situation as "vulnerable employment." Health system funding on the basis 
of social security contributions on wages has been seriously undermined by the growth of this "informal" sector. As for them, fiscal revenues depend on the functioning of the tax system, which faces many challenges related to corruption.

\section{Common trends attributable to the same international recommendations}

Health system reforms implemented in the 199os proceeded at varying paces in the newly independent states, but were driven largely by two international organizations: the World Bank and USAID. Their main recommendations were to decentralize the public health system, encourage the emergence of a private health sector, and restructure primary health care (first point of contact) around the function of the general practitioner or family doctor. However, the populations of the former Soviet Union have a highly specific behavior with regard to accessing health care. The internal contradictions of the Soviet system dealt a severe blow to primary health care from the 1970s onwards, and the population soon became accustomed to consulting specialists. Recourse to hospitalization and specialists is still firmly rooted in mentalities, as the population is wary of the reformed public health system and has trouble understanding the role of family doctors, who they feel lack legitimacy, and symbolize the privatized health care.

In all three countries, we observe the same periodization. The 1990s were a period of crisis, adaptation - often through decline and recession - and the introduction of the first round of reforms, including the legalization of a private sector. The 20oos represented new economic growth (in the three countries, GDP returned to its 1990 level between 2000 and 2005, depending on the indicators), which has been extremely rapid and taken a highly specific form in Azerbaijan with the oil boom. While there is differentiation in the type and pace of growth, the main divergences seem to be related to ideological and political choices, in which the period of the mid-20oos represented a turning point.

\section{National trajectories}

The Armenians we interviewed were critical of the organization of the Soviet health system but stressed the importance of state-guaranteed access to health care. The path envisaged for the extension of public health cover is that of pragmatic gradualism, and at least in discourse, the respondents often refer to "French style" social security or in general to a "protective" European model. In Azerbaijan, the gulf has grown between the official presentation of a health system that has changed little since Soviet times and the reality on the ground, which is highly dysfunctional and segmented. The countries mostly cited in 
comparison or discussion of the Azerbaijani health system are Iran, Russia, and Turkey. In Georgia, the discourse is of a break with the past and radical change, which characterized the second half of the 2000s. The countries cited by some respondents as possible sources of inspiration are the United States and, to a lesser extent, countries of a comparable size like Estonia.

Despite of their common Soviet legacy in public health system, the South Caucasian countries have oriented their policy choices in rather different ways. The choice between either a 'socialist' model or a neo-liberal one are to be understood in light of the social and political history of each country and their geopolitical strategies. 